\title{
Giant sigmoid diverticulum mimicking bowel perforation
}

\author{
Ahmad Muneeb, Stephen Lam
}

Department of General Surgery, Wexham Park Hospital, Wexham, Slough, UK

\section{Correspondence to} Mr Ahmad Muneeb, ahmadfrcs@hotmail.com

Accepted 14 December 2017

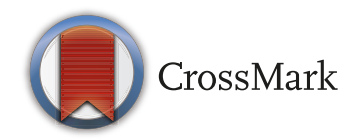

To cite: Muneeb A, Lam S. BMJ Case Rep Published Online First: [please include Day Month Year]. doi:10.1136/bcr-2017223394

\section{DESCRIPTION}

An 88-year-old bedbound woman from a nursing home with a background of dementia was transferred by ambulance to accident and emergency with abdominal distension, pain and a decreasing level of consciousness. On examination the patient was feverish, hypotensive and tachycardic, consistent with sepsis. The abdomen was distended, with tenderness and guarding at the paraumbilical area. Digital rectal examination showed faecal loading. She was resuscitated with intravenous fluids, and blood

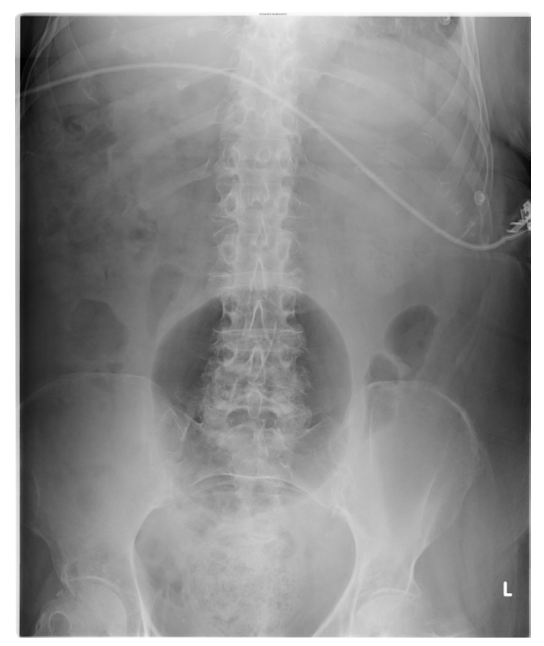

Figure 1 Plain abdominal X-ray showing a large central air pocket.

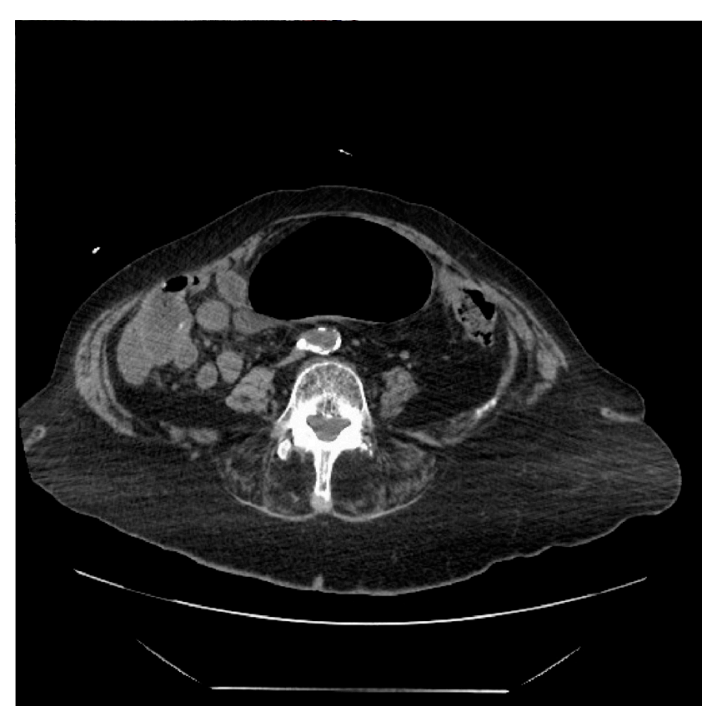

Figure 2 Axial CT image showing a $11 \times 6 \mathrm{~cm}$ giant diverticulum.

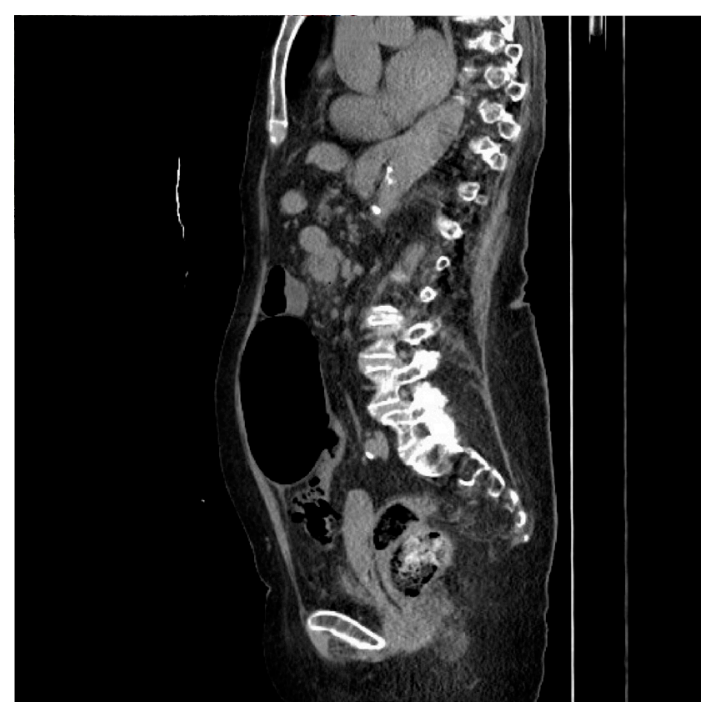

Figure 3 Sagittal CT image showing the giant diverticulum anterior to the sigmoid colon.

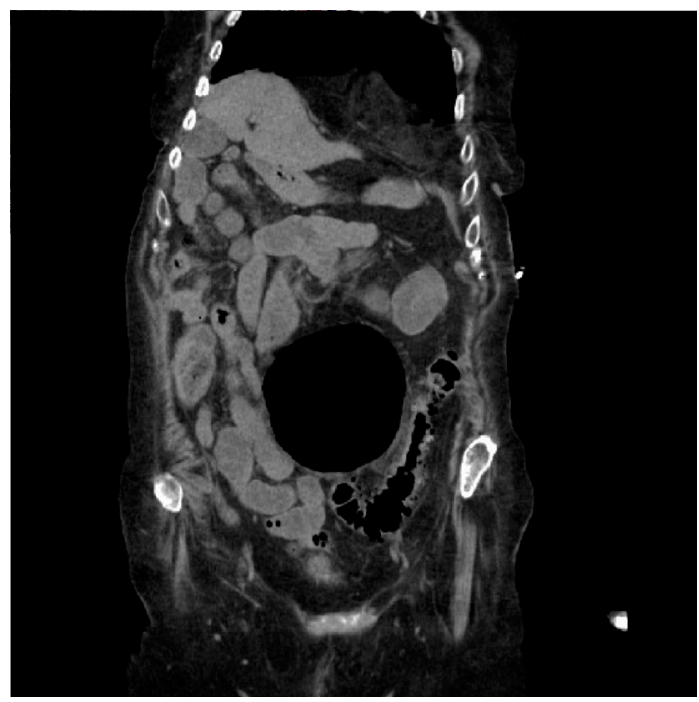

Figure 4 Coronal CT image showing the giant diverticulum.

results showed a raised lactate $(4.1 \mathrm{mmol} / \mathrm{L})$, acute kidney injury and raised inflammatory markers (white cell count $9.1 \times 10^{9} / \mathrm{L}$ and $\mathrm{C}$ reactive protein $410 \mathrm{mg} / \mathrm{L}$ ). A chest X-ray did not demonstrate any free air under the diaphragm, and abdominal X-ray showed a large air shadow in the centre of the abdomen (figure 1).

The working diagnosis was a localised perforation, and therefore a CT scan of the abdomen and pelvis was urgently arranged. The CT demonstrated 


\section{Learning points}

- Giant colonic diverticulum (GCD) is rare, with less than 200 cases reported in the literature.

- The CT findings of large diverticulum can be mistaken for a contained bowel perforation, and it is important to differentiate between the two pathologies as their managements can be different.

- GCD can be complicated by volvulus, bowel obstruction, perforation, abscess formation, sepsis and rectal bleeding. ${ }^{23}$

- Two per cent of giant diverticulum is associated with malignancy, either within it or distal to it, so it is important to arrange flexible sigmoidoscopy before elective bowel resection. ${ }^{2}$ However, a clear causal association between giant diverticulum and malignant transformation has yet to be established.

- Although conservative management is possible for high-risk surgical patients (as in this case), surgical resection of the diverticulum is the mainstay of treatment for $G C D{ }^{3} A$ review of 16 cases of GCD treated with sigmoidectomy and en bloc resection of the diverticulum reported no postoperative deaths and a morbidity rate of $6 \%$.

- Due to the risk of complications from GCD and the low reported morbidity and mortality from their surgical resection, elective surgery could be considered as a management option for uncomplicated GCD. one large air-filled outpouching $(11 \times 6 \mathrm{~cm})$ anterior to the sigmoid colon (figure 2), which was initially (prior to a formal radiology report) thought to be a contained bowel perforation, although there was no evidence of any other pockets of free air in the abdominal cavity. After review of the images by a consultant radiologist, the CT was reported as a giant sigmoid diverticulum (figures 3 and 4 ) originating from the sigmoid colon, with inflammatory changes suggestive of acute diverticulitis. The patient was managed conservatively with intravenous fluids and antibiotics.

Contributors Initial idea by AM. AM and SL contributed to the first draft and acquisition of data. Consent was obtained by SL. AM and SL wrote and agreed on the final draft.

Competing interests None declared.

Patient consent Obtained.

Provenance and peer review Not commissioned; externally peer reviewed.

(C) BMJ Publishing Group Ltd (unless otherwise stated in the text of the article) 2018. All rights reserved. No commercial use is permitted unless otherwise expressly granted.

\section{REFERENCES}

1 Nigri G, Petrucciani N, Giannini G, et al. Giant colonic diverticulum: clinical presentation, diagnosis and treatment: systematic review of 166 cases. World J Gastroenterol 2015;21:360-8.

2 Altaf N, Geary S, Ahmed I. Giant colonic diverticulum. J R Soc Med 2005:98:169-70.

3 McQuade KL, Foreman ML. Giant colonic diverticulum. Proc (Bayl Univ Med Cent) 2008:21:25-6.

Copyright 2017 BMJ Publishing Group. All rights reserved. For permission to reuse any of this content visit

http://group.bmj.com/group/rights-licensing/permissions.

BMJ Case Report Fellows may re-use this article for personal use and teaching without any further permission.

Become a Fellow of BMJ Case Reports today and you can:

- Submit as many cases as you like

Enjoy fast sympathetic peer review and rapid publication of accepted articles

- Access all the published articles

Re-use any of the published material for personal use and teaching without further permission

For information on Institutional Fellowships contact consortiasales@bmjgroup.com

Visit casereports.bmj.com for more articles like this and to become a Fellow 